\title{
Chinese Conception of International Law as the Response to the Challenges of Today
}

\author{
Ella Gorian \\ Kristina Gorian \\ Vladivostok State University of Economics and Service \\ Email: eldirect@mail.ru, ella-goryan@yandex.ru
}

\section{Doi:10.5901/mjss.2015.v6n3p236}

\begin{abstract}
The article analyses different interpretations of the norms and principles of international law by subjects of international law, which represent different cultures, makes it impossible to effectively solve the problems, confronting the world community. The clash of civilizations, which the United Nations is trying to solve through the dialogue of the last decade speaks about different for many cultures perception of human values, which is reflected in approaches to the interpretation of the principles of international law. The authors raise the question about the possibility of perception as ideas of problem solution of other, nonWestern, i.e., non-Christian cultures, represented by subjects of international law, occupying more and more leading positions in selected regions. The article analyzes the Chinese concept of international law, the basic principles which are used in other Asian countries (India, Thailand, Myanmar, Nepal, Pakistan, Afghanistan, Mongolia, Indonesia) to regulate international relations among themselves and even with the European states and North America. The authors argue the appropriateness and adequacy of this concept to resolve territorial disputes, the establishment of a sustainable trade and economic relations, the formation of effective legal models of minimization of ethno-cultural conflicts, achievements of civilization harmonization in international legal cooperation.
\end{abstract}

Keywords: fragmentation of international law, the concept of international law, the conflict of civilizations.

\section{Introduction}

Globalization is an objective process. It can't be stopped or avoided. Globalization makes the world joint, what has the pluses and minuses. It destroys lasting relationships, creates new conditions for development Many people consider in it as one of the sources of global conflict and international terrorism (V.F. Antipenko and A.V. Antipenko, 2014). The events of the last decades prove the inefficiency of the modern system of international law and the impossibility of using the existing universal mechanisms to ensure peace, security and prosperity of mankind. "Westernization" of many states, accompanied by the idea of the rule of law in the Western sense, leads to the hidden and even open (Islamic State in Iraq and Syria - ISIS) rejection with subsequent confrontation. The efforts of states to solve problems with the use of regional international legal mechanisms can be called successful.

International lawyers, theorists, and practitioners, give different explanations to the imperfection of the modern international legal system and the ineffectiveness of international mechanisms in the regulation of these relations. So, the scholars point to such phenomenon as "fragmentation" of international law" among the reasons that threaten the world order (I. Brownlie 1988). The problem of fragmentation of international law is the subject of great attention of international lawyers: Koskenniemi M., Hafner G., Dupuy P. M., Simma B., Martineau A.-Ch., Jouannet E., Abi-Saab G., Rao P. S., Fischer-Lescano A., R.A. Kolodkin R., Poiedynok O. etc., it is included in the agenda of the international law Commission of the UN, it is discussed in the Sixth Committee of the UN General Assembly (O.R. Poiedynok, 2013).

Fragmentation (at least its threat) is seen in the proliferation (growth, increase, expansion) of international legal norms and institutions, in the autonomy or self-sufficiency of some international legal regimes, in the dissemination of international law in those spheres of relations that were not previously considered suitable for international legal regulation. Also it is indicated on regionalization and specialization of international law, in particular in areas such as human rights and international trade, the creation of international courts and other bodies, applying, interpreting the international law and having competence, which coincides completely or partially. This leads to conflicts between legal norms and regimes, interpretation and application of the same norms in various situations, to the collapse of the integral and homogeneous international legal system (R.A. Kolodkin, 2005).

The perception of fragmentation of international law depends on the nature of the understanding by the specific 
researcher of international law in general. So, established in the Russian legal science and approved by the Commission under international law of the UN, the perception of international law as a unified and holistic law (universalist or constitutional approach) is still not shared by those scholars who see it as just a collection of loosely interconnected subsystems (particular or pluralistic approach). Thus, the universalist choose as a starting point, the general international law and, as a rule, deny the existence of self-contained regimes, highlighting the danger that bears fragmentation. Particularists incline to apply the methods of sociological analysis of certain characteristics of the individual regimes. In their opinion, special regimes are self-sufficient, and fragmentation is a natural phenomenon and even useful (O.R. Poiedynok, 2013).

On the other hand, the scientists talk about such a result of globalization, as the formation as opposed to the Westphalian system of international relations a kind of "Eastphalian" system, highlighting as an indicator of a different understanding of the content of state sovereignty, which is a key element of the Westphalian system. The term "Eastphalian" sovereignty has been used by scholars (Kim Sung Won, David Fidler, Sumit Ganguly, Tom Ginsburg, Lo Chang Fa) to describe China's view as a political authority, in the same manner as "Westphalian" has been used to describe Western Europe's sovereignty.

In our opinion, these concerns arise from researchers because of fear to perceive international law differently as a legal system that can develop only in the mainstream of Western Christian civilization. Historically, the science of international law accrued and developed in the bosom of the Catholic Church and its theological thought (Bartolome de Las Casas, Francisco de Vitoria, Francisco Suarez, and others), due to which the international law (law of Nations) was called the right of "Christian Nations". Later Protestant theologian Hugo Grotius was the first scientist who, in fact, separated by international law from Christian theology and created a rational conception of international law based on natural law of the mind. However, this did not prevent later Woolsey from defining international law as a set of "rules that Christian states shall recognize mandatory in relations with each other and also to their citizens" (C.C. Hyde, 1992).

The events of the last decades indicate attempts to "impose" the international community model of regulation of relations with states, leading political situation. Not accidentally nihilistic approach to the administration of U.S. President George W. Bush to international law (the so-called "foreign policy conception of the Bush", which envisaged the possibility of preventive war, regardless of the requirements of international law (The National Security Strategy of the United States of America, http://nssarchive.us/NSSR/2002.pdf, 2002) is associated with the fact that this administration was dominated by the so-called "neo-conservatives" whose religious worldview called "neo-Protestant". The essence of this neo-Protestant ideology lay in the fact that God supposedly gave USA with a special mission in the world, which allows to ignore the norms and principles of international law, and the President Bush was convinced in his being "chosen people", which is especially apparent in unauthorized by the UN Security Council war in Iraq (A.A. Merezhko, 2010).

A similar hypothesis "That's what makes us exceptional" was used by Barack Obama during his address to his people on 10 September 2013 in connection with the situation in Syria (K. Tumulty, 2013). It is noteworthy that on the question of the beginning of the war in Iraq and Syria the collision of two concepts of international politics and international law, namely, the "neo-Protestant" (K.V. Gorian, 2013) and Orthodox Christian (Catholic and Orthodox), the members of which called for a peaceful solution of international conflicts were observed (D., Milbank, 2004; and M. Fisher, 2013).

Based on the foregoing, in the legal science in the framework of the theory of "Christian international law" is observed not so much a single, Christian international law but the three main concepts of this law: Catholic, Orthodox and neo-Protestant (A.A. Merezhko, 2010), which is reflected in the actions of the respective states in the international arena and affect the effectiveness of international legal norms, especially, jus cogens.

Over the past decades, researchers have published a number of works on Islamic conception of international law (N.V. Zhdanov, 2013; and E.V. Gorian 2013). In its turn, the UN insists on dialogue of civilizations: in the period 20022007 such dialogue was declared by UNESCO as priority (UNESCO, 2007), in 2007, the UN General Assembly has proclaimed 2010 the year of the International year for the rapprochement of cultures (United Nations, 2007).

The term "civilization" began to be used in past 30 years in international legal discourse as a necessary category to describe the cultural diversity that is inherent in the global community (L. Kirsanova and O. Korotina, 2014). Although initially this term was used for qualitative determination of population (peoples) of the metropolitan countries and their satellites, emphasizing their higher status compared to people of the colonies. Therefore, international law was developing as a law of "civilized Nations" (see, for example, Art. 38 of the Statute of the International court of UN), who were the bearers of European, so-called "Western" culture, which displays the ideas and worldview of Western Christian civilization, according to the terminology of Huntington (S. Huntington, 1994).

The aforsaid allows us to pose the question about the necessity of using cultural method of studying international law, because the cultural identity (commitment to certain values) defines the government's approach to understanding the 
theory and its practical application, in international relations.

Modern scholars increasingly argue on the need for use of an interdisciplinary approach to the study of international law, since the events of the last hundred years demonstrates "the failure of the positivist, rational approach to the regulation of international relations. The researchers who pay attention to the sociological (A.A. Merezhko, Law. http://www.itcs.org.ua/sites/default/files/content/files/news/doklad_merezhko.pdf, 2012; and Y.V. Kozhenko and A.G. Kravchenko, 2007) and conflictology (V.F. Antipenko and A.V. Antipenko, 2014) approaches in the study of the nature of international law talk in their works. In our opinion, the cultural approach deserves special attention, the cultural diversity is also reflected in the different legal systems of states, which, however, forms a part of the total legal family, and in different attitude of states to international law. The inability of modern international law to deal effectively, in particular, with international conflicts is explained by the presence of "conflict of civilizations" (Hutnington, 1994) and the crisis of Western Protestant paradigm of Christian civilization (V.F. Antipenko and A.V. Antipenko, 2014).

In his study of Huntington defines a civilization as a cultural community of the highest rank, as the broadest level of cultural identity people (S. Huntington 1994). He distinguishes Western, Confucian, Japanese, Islamic, Hindu, SlavicOrthodox, Latin American and African civilization. In his opinion, the most significant conflicts of the future will unfold along the fault lines between civilizations, explaining that by their dissimilarity in their history, language, culture, traditions, (S. Huntington 1994). Civilizations differ in the values, the principles on which are build the relations: interpersonal, social, public authority and, finally, the interstate. At first glance, these values are similar, they are supported, at least at the level of signing and recognition of the universal international legal instruments, the vast majority of states - human rights, rule of law, the state sovereignty and so on. But, as the practice of international relations shows, the understanding of the content of these values and, most importantly, their willingness to stand them, depend, not least, from the belonging of the state to one or another civilization, the characteristics of the legal culture of a specific legal system.

\section{Research Methodology}

The aforsaid allows us to pose the question about the necessity of using cultural method of studying international law, because the cultural identity (commitment to certain values) defines the government's approach to understanding the theory and its practical application, in international relations.

Modern scholars increasingly argue on the need for use of an interdisciplinary approach to the study of international law, since the events of the last hundred years demonstrates "the failure of the positivist, rational approach to the regulation of international relations. The researchers who pay attention to the sociological (A.A. Merezhko, Law. http://www.itcs.org.ua/sites/default/files/content/files/news/doklad_merezhko.pdf, 2012; and Y.V. Kozhenko and A.G. Kravchenko, 2007) and conflictology (V.F. Antipenko and A.V. Antipenko, 2014) approaches in the study of the nature of international law talk in their works. In our opinion, the cultural approach deserves special attention, the cultural diversity is also reflected in the different legal systems of states, which, however, forms a part of the total legal family, and in different attitude of states to international law. The inability of modern international law to deal effectively, in particular, with international conflicts is explained by the presence of "conflict of civilizations" (Hutnington, 1994) and the crisis of Western Protestant paradigm of Christian civilization (V.F. Antipenko and A.V. Antipenko, 2014).

In his study of Huntington defines a civilization as a cultural community of the highest rank, as the broadest level of cultural identity people (S. Huntington, 1994). He distinguishes Western, Confucian, Japanese, Islamic, Hindu, SlavicOrthodox, Latin American and African civilization. In his opinion, the most significant conflicts of the future will unfold along the fault lines between civilizations, explaining that by their dissimilarity in their history, language, culture, traditions, (S. Huntington, 1994). Civilizations differ in the values, the principles on which are build the relations: interpersonal, social, public authority and, finally, the interstate. At first glance, these values are similar, they are supported, at least at the level of signing and recognition of the universal international legal instruments, the vast majority of states - human rights, rule of law, the state sovereignty and so on. But, as the practice of international relations shows, the understanding of the content of these values and, most importantly, their willingness to stand them, depend, not least, from the belonging of the state to one or another civilization, the characteristics of the legal culture of a specific legal system.

\section{Findings and Discussion}

Special attention deserves the Chinese concept of international law, which is the basis of so-called «Eastphalian Sovereignty» (A. Coleman and J.N. Maogoto, 2013). The basis of concept is in the Five Principles of Peaceful Coexistence (United Nations, http://houston.china-consulate.org/eng/nv/t140964.htm, 1958). Coleman and Maogoto remark the instructive role of these Principles - India, Asia's other rising power, also considers them (Panchsheel as they are 
termed in India) important in how it approaches its foreign policy and diplomatic relations in the twenty-first century (Coleman and Maogoto 2013, p. 260). Other Asian states have not only adopted the Five Principles as being indicative of a broader Asian perspective on sovereignty and diplomatic practice, but also rely on these Principles in their dealings with one another. The Five Principles were confirmed at the Bandung Summit on Afro Asian Solidarity in 1955, an important precursor to the non-Aligned Movement. The essence of the Five Principles is not so much that they demarcate a new approach to international law and relations; rather they are elaborations of already enshrined ideas of sovereignty. Their importance is pegged on the rise of China (and India): 1) mutual respect for each other's territorial integrity and sovereignty; 2) mutual non-aggression; 3) mutual non-interference in each other's internal affairs; 4) equality and cooperation for mutual benefit; 5) peaceful co-existence (agreement) (United Nations, 1958).

Over the past 50 years, in the spirit of the Five Principles of Peaceful Co-existence, China settled border problems left over by history with Myanmar, Nepal, Pakistan, Afghanistan, and Mongolia and solved the problem of doublenationality of Indonesian-Chinese with Indonesia, thus setting up an image of peace in Asia and becoming an example for strengthening regional stability and consolidating unity of Asian countries. Statistics show that by 1976, the year in which Premier Zhou Enlai passed away, there had been more than 90 countries who recognized the Five Principles in the form of government documents jointly issued with China, and, on this basis, more than 100 countries established diplomatic relations with China. Thus, India also solved successfully its border disputes with Myanmar and Nepal according to the Five Principles.

Meanwhile, the Five Principles also crossed ideological gap and broke the barrier between western, oriental cultures by winning recognition from western countries. In 1956, Finland, Denmark, Sweden, France and Belgium introduced the Five Principles into related documents; after the 1970s, Japan, Britain, Holland, Western Germany, Australia and the United States accepted the Five Principles one after another and wrote them into friendship agreements or joint communiques signed with China. During half a century, the Five Principles have been included into more than 160 international documents. Just as former Indian President Kocheril Raman Narayanan put it, the fact that a principle agreement signed between two countries got accepted by most world countries is very rare in the history of international relations (The Five Principles...).

Why the Five Principles are so widely accepted by the international community? David Abel, former minister of Myanmar cabinet, gave his explanation in an interview. He believes that the Five Principles proposed by China included basic norms in international relations, and summarized the purposes and principles of the UN Charter in a succinct way, that's why they can be widely recognized.

The Five Principles stand for non-aggression, non-interference and peaceful co-existence, thus providing a practical way in solving border disputes and handling relations between big and small countries.

The Five Principles also lay stress on equality and recognition of the diversity of the world by advocating the norms of "seeking common ground while reserving differences" and "do not impose on others what you yourself do not desire", which demonstrate the democratic sprit in modern international relations and needs of the vast developing countries and therefore are in the fundamental interests of world people.

Former Australian Prime Minister Robert James Lee Hawke once emphasized that the notion of "mutual benefit" put forward in the Five Principles serves as a base for creating a safer world, which called for a sprit of cooperation, and it is where the vitality of the Five Principles lies(The Five Principles...).

Li has emphasized an existence of Chinese conception of international law: «Despite frequent references in and out of China to "Chinese international law", there is no such thing as "Chinese international law" any more than there is such a thing as "Chinese mathematics;" there can only be a Chinese theory and practice of international law» (Z. Li, 2001).

Differences in Western and Chinese concepts of international law are observed at the level of interpretation of the principles of international law. Xue expresses doubts on the same approach to their interpretation: "When the rule of law, democracy, and human rights are being advocated at the international level, they often tend to represent essentially one type of ideology, one form of culture, and one kind of political system» (H. Xue, DOl: http://dx.doi.org/10.1017/S20 $44251310000068,2011)$. What is the peculiarity of the Chinese approach? The researchers note that China's historical experiences tend to emphasize that the greatest threat to human rights take place during periods of instability, regime change, and threats to the authority of the ruling polity. The focus is on the more "fundamental" questions of maintaining equality, peace and security, and equal access to development. In all of this, Eastphalian sovereignty is merely seeking to find a path through norms of international law that truly are universal, rather than serving the interests of a few (A. Coleman and J.N. Maogoto, 2013; and S.F. Litvinova, 2014). China is "seeking to find the "legitimate" norms of international law that truly represent all the actors on the world stage» (A. Coleman and J.N. Maogoto, 2013). As Petersen notes: "Therefore, international law only sets up a framework, leaving room for different cultural conceptions of 
political order and different social circumstances, for which an autocratic rule might sometimes be more appropriate than an unstable democracy" (N. Petersen, DOI: http://dx.doi.org/10.1017/S2044251310000342, 2011).

A significant contribution to the study of the Chinese concept of international law made Judge Xue Hanqin (International Court of Justice), who published series of lectures for the Hague Academy of International Law (H. Xue, 2012). Xue continues work begun two decades earlier in a special Hague Academy course by Xue's mentor, scholar Wang Tieya (T. Wang, 1990).

In her book Xue notes that, like other Third World countries that oppose imperialist and colonialist rules and principles of international law, China has never rejected international law itself. Indeed, the People's Republic endorsed the purposes and principles of the UN Charter from the moment of its founding, along with the importance of the sovereign equality of all states (S.L. Seck, DOI: 10.1017/S2044251314000253, 2015, p. 209). China's approaches to the recognition of states («Taiwan issue») and the settling of territorial disputes (Hong Kong) are also analyzed.

Xue first highlights the continuing importance for China's approach to international law of the inviolability of sovereignty and the principle of non-interference. Sovereignty is "a claim about the way in which how different political and social systems, different forms of civilization and culture should correlate and treat each other in international relations". For China, these principles and the idea of nationhood remain important, notwithstanding the influence of natural law in international human rights, environmental, criminal, and humanitarian law (S.L. Seck, DOI: 10.1017/ S2044251314000253, 2015).

A special chapter focuses on China's conception of human rights. She emphasizes the need to consider human rights from a notably the importance of the right to development, and the belief that collective and communal interests may at times prevail over those of the individual (S.L. Seck, DOI: 10.1017/S2044251314000253, 2015).

Chinese perspectives of the international law of sustainable development are inextricably linked to the right to development, and the need to address the "inequality and underdevelopment of the present generation", a prerequisite to generational equity. Actions on climate change should thus accord with the principle of common but differentiated responsibilities, and account should be taken of historical emissions by industrialized countries - the pursuit of sustainable development should serve as the guiding principle for international actions on climate change' (S.L. Seck, DOI: 10.1017/S2044251314000253, 2015).

Excluded from the United Nations prior to 1971, China was subsequently very selective about the international organizations with which it would engage, preferring those with technical, social, and cultural objectives that were less sensitive politically. Following China's adoption of economic reforms, China ratified and acceded to many international treaties, and quickly joined all major UN institutions from human rights to nuclear non-proliferation to trade (A.P. Alekseenko 2014, p. 37). It also greatly increased regional co-operation, including with ASEAN and the Shanghai Cooperation Organisation (S.L Seck, DOI: 10.1017/S2044251314000253, 2015).

Despite the dramatic change in China's approach and engagement with international law over sixty years, China has remained deeply committed to the principles of sovereign equality, territorial integrity, and non-interference. To fully appreciate this stance, and thus the Chinese perspective on international law, requires an understanding of history, and of political, economic, and social context (S.L. Seck, DOI: 10.1017/S2044251314000253, 2015).

\section{Conclusion}

Summarizing the abovementioned, we believe that the key aspects of modern Chinese concept of international law can become guidelines for the development and further improvement of international law. We should agree with Coleman and Maogoto, who think, that perhaps it is the West that needs to make an adjustment. It may be that the West can learn from China's concept of "one state, two systems" and apply it on a global level: "one globe, different systems" (A. Coleman and J.N. Maogoto, 2013). International legal behavior of China tends to be more consistent and stable than its foreign policy behavior. While China's practice in international law follows overall guidelines of its foreign policy, as most of the countries do, it never intends to act as it pleases outside the parameters of recognized international legal norms and rules (Z. Li, 2001). The more will increase China's role at the regional level, the more successful will be its participation in peacekeeping initiatives, the more acceptable to the world community will be approaches to the regulation of international relations.

\section{References}

Alekseenko, A.P., 2014. Constitution as a factor of investment attractiveness of the state: experience of constitutional construction of the PRC. History of State and Law, 19, pp. 36-39. 
Antipenko, V.F., and Antipenko A.V., 2014. Conflictology in International Antiterrorism Lawmaking. Odessa: Feniks.

Brownlie, I. 1988. The Rights of Peoples in Modern International Law. In J.Crawford (Ed.), The Rights of Peoples. Oxford: Clarendon Press.

Coleman, A., and Maogoto J.N., 2013. "Westphalian" Meets "Eastphalian" Sovereignty: China in a Globalized World. Asian Journal of International Law, 3, p. 237-269. Doi:10.1017/S2044251313000179.

Fisher, M., 2013. Vladimir Putin's New York Times op-ed, annotated and fact-checked. Washington Post, Sept. 12

Gorian, E.V., 2013. Islamic Conception of International Law. In V.N. Kubalskiy (Ed.), Problems of Effectiveness of International Law (pp. 34-38). Kyiv, Ukraine: V.M. Koretsky Institute of State and Law.

Gorian, K.V., 2013. Neo-Protestant Conception of International Law as one of the Determinants of International Conflicts. In N.Pashinsky (Ed.), International Readings in International Law in memory of Professor P.E. Kazansky (pp. 543-546). Odessa: National University "Odessa Law Academy".

Huntington, S., 1994. The Clash of Civilizations? Polis, 1, 33-48.

Hyde, C.C., 1922. International law chiefly as interpreted and applied by the United States. Boston : Little, Brown, and company.

Kolodkin, R.A., 2005. Fragmentation of International Law. Moscow Journal of International Law, 2, pp. 38-61.

Kirsanova, L., and Korotina O., 2014. On the Contents of the Protest Conscience in Russia. Wolrd Applied Sciences Journal 31(5): 930934.

Kozhenko Y.V. and Kravchenko A.G., 2007. Sociology of Law: series of lectures. Taganrog, Taganrog Institute of Management and Economics.

Litvinova, S.F., 2014. Formation of legal traditions in the PRC as a result of consistent legal activitiy. Law and politics, 8, $1241-1248$.

Li, Z., 2001. Legacy of Modern Chinese History: Its Relevance to the Chinese Perspective of the Contemporary International Legal Order. Singapore Journal of International and Comparative Law, 5, 314-326.

Merezhko, A.A., 2010. Problems of the Theory of International Public and Private Law. Kyiv: Justinian.

Merezhko, A.A., 2012. Sociology of International Law. Problems and Perspectives of Sociology of International Law. http://www.itcs.org. ua/sites/default/files/content/files/news/doklad merezhko.pdf.

Milbank, D., 2004. Pope Presses Bush on Iraq Violence. Washington Post, June 5.

Petersen, N., 2011. International Law, Cultural Diversity, and Democratic Rule: Beyond the Divide Between Universalism and Relativism. Asian Journal of International Law, 1, pp. 149-163. DOI: http://dx.doi.org/10.1017/S2044251310000342.

Poiedynok, O.R., 2013. Fragmentation of international law: functional, regional, and institutional dimensions. Kyiv, Institute of International Relations.

Seck, S.L., 2015. Review of Hanqin XUE 'Chinese Contemporary Perspectives on International Law: History, Culture and International Law (Pocketbooks of The Hague Academy of International Law)'. Asian Journal of International Law, 5, 209-210. DOI: 10.1017/S2044251314000253.

The Five Principles of Peaceful Co-existence: fundamental and everlasting norms guiding international relations. (2004, June 28). Retrieved March 11, 2015, from http://houston.china-consulate.org/eng/nv/t140964.htm.

The National Security Strategy of the United States of America. (2002, September 17). In National Security Strategy Archive. Retrieved March 11, 2015, http://nssarchive.us/NSSR/2002.pdf.

Tumulty, K., 2013. American exceptionalism, explained. Washington Post, Sept. 12.

UNESCO, 2007. Records of the General Conference of United Nations Educational, Scientific and Cultural Organization, Thirty-fourth Session, Paris, 16 October-2 November 2007. Volume 1: Resolutions, chap.V.

United Nations, 1958. Agreement between the Republic of India and the People's Republic of China on trade and intercourse between Tibet region of China and India (1954). UN Treaty series Volume 299.

United Nations, 2007. Promotion of interreligious and intercultural dialogue, understanding and cooperation for peace. Resolution adopted by the General Assembly on 17 December 2007. A/RES/62/90.

Wang, T., 1990. International Law in China: Historical and Contemporary Perspectives. Recueil des cours, 221, $195-369$.

Xue, H., 2012. Chinese Contemporary Perspectives on International Law: History, Culture and International Law. Leiden/Boston: Brill/Nijhoff.

Xue, H., 2011. Meaningful Dialogue Through a Common Discourse: Law and Values in a Multi-Polar World. Asian Journal of International Law, 1, 13-19. DOI: http://dx.doi.org/10.1017/S2044251310000068.

Zhdanov, N.V., 2003. Islamic Conception of Legal Order. Moscow: International Relations. 